\title{
Sources, cycling and transfer of mercury in the Labrador Sea (Geotraces -Geovide cruise)
}

\author{
Cossa Daniel ${ }^{1,{ }^{*}}$, Heimbürger L.E. ${ }^{2}$, Sonke J.E. ${ }^{3}$, Planquette H. ${ }^{4}$, Lherminier Pascale ${ }^{5}$, \\ García-lbáñez M.I. ${ }^{6}$, Pérez $\mathrm{Ff}^{6}$, Sarthou G. ${ }^{4}$
}

${ }^{1}$ ISTerre, Université Grenoble Alpes, CS40700, F-38041 Grenoble, France

${ }^{2}$ Aix Marseille Université, CNRS/INSU, Université de Toulon, IRD, Mediterranean Institute of Oceanography (MIO), UM 110, Marseille 13288, France

${ }^{3}$ CNRS, GET-OMP, Université de Toulouse, 14 Ave. E. Belin, Toulouse F-31240, France

${ }^{4}$ LEMAR, Université de Bretagne Occidentale, Plouzané F-29280, France

${ }^{5}$ Ifremer, Brittany Center, LPO, BP70, Plouzané F-29280, France

${ }^{6}$ Instituto de Investigaciones Marinas, CSIC, Eduardo Cabello 6, Vigo E-36208, Spain

*Corresponding author : Daniel Cossa, email address : $\underline{\text { dcossa@ifremer.fr }}$

\begin{abstract}
:
The Labrador Sea links the Arctic and North Atlantic oceans and constitutes one of the main entrances of atmospheric inputs into the Ocean's interior. We report here the first high-resolution $\mathrm{Hg}$ distribution pattern along a transect from Greenland to Labrador coasts sampled after the 2014 winter convection. Total $\mathrm{Hg}$ concentrations in unfiltered (HgTUNF) samples ranged from $0.25 \mathrm{pmol} \mathrm{L}-1$ to $0.67 \mathrm{pmol} \mathrm{L}-1$ averaging $0.44 \pm 0.10 \mathrm{pmol} L-1(n=113,1 \sigma)$. Concentrations in filtered samples $(\mathrm{HgTF},<0.45 \mu \mathrm{m})$ represented from 62 to $92 \%$ of the HgTUNF and exhibited a similar distribution. High HgTUNF concentrations were found (i) in the waters of the Labrador Current, which receive desalted waters from the Canadian Arctic Archipelago, and (ii) in the waters over the Labrador shelf and rise. In the Labrador Sea Waters formed during the 2014 winter convection, HgTUNF concentrations were low $(0.38 \pm 0.05 \mathrm{pmol} L-1, n=23)$, and increased gradually with depth (up to $>0.5 \mathrm{pmol} L-1$ ) in the Northeast Atlantic Deep Waters. HgTF correlates with apparent oxygen utilization implying that atmospheric deposition, biological uptake, and microbial respiration control the $\mathrm{Hg}$ distribution in the Labrador Sea. Subtracting the amount of $\mathrm{Hg}$ released during organic matter remineralization allows us to identify a $\mathrm{Hg}$ and organic matter enriched fraction, which originates from fluvial sources in the Canadian Arctic Archipelago waters. This fraction is transferred southward, in surface waters with the Labrador Current, and at depth with the lower limb of the Atlantic Meridional Overturning Circulation. Climate warming, which will increase the mobilization of $\mathrm{Hg}$ from thawing permafrost, would consequently increase the Arctic export of $\mathrm{Hg}$ initially associated with organic matter.
\end{abstract}




\section{Highlights}

- The Labrador Sea Water formed during the 2014 winter convection contains very low Hg. Labrador Current waters, from the Canadian Arctic Archipelago, are Hg-enriched. $\rightarrow \mathrm{Hg}$ exhibits a nutrient-like distribution in the central Labrador Sea.

Keywords : Labrador Sea Mercury North Atlantic 


\section{Introduction}

Mercury $(\mathrm{Hg})$ is a volatile trace element of great environmental concern, which is delivered to the Oceans mostly as dissolved and particulate oxidized species $\left(\mathrm{Hg}^{\mathrm{II}}\right)$ in rivers and precipitations, but also as elemental $\mathrm{Hg}\left(\mathrm{Hg}^{0}\right)$ during ocean-atmosphere gas exchange (e.g., Fitzgerald et al., 2007; Pirrone and Mason, 2009; Obrist et al., 2017). After its advection/deposition onto sea surface, $\mathrm{Hg}$ can be reinjected into the atmosphere via photoreduction in surface waters, transported with currents, taken up by bio-pumping (i.e., sorbed into/onto plankton), and vertically transferred with settling material and potentially released at depth (e.g., Mason et al., 2012; Lamborg et al., 2014). Mercury is incorporated this way into the intermediate and deep waters of the oceans, following a "regenerative scavenging" recycling process, akin to the nutrient-like behavior described for many other trace elements (e.g., Lamborg et al., 2016).

The Labrador Sea (LS, Fig. 1) is the main site in the North Atlantic Ocean where intermediate and deep waters are produced during wintertime ocean convection (e.g., Talley and McCartney, 1982; Dickson et al., 2008). This convection mixes Arctic outflow and Atlantic waters with underlying layers and produces a particular intermediate water mass called the Labrador Sea Water (LSW). Irminger and Nordic seas are the other basins of the North Atlantic Ocean where convection leads to the formation of intermediate and deep waters, namely the Denmark Strait Overflow Water (DSOW) and the Iceland-Scotland Overflow Water (ISOW). Underlying LSW, the cold and fresh West Greenland Current flows northwestwardly along the Greenland coasts, whereas the Labrador Current flows southeastwardly along the Labrador shelf (Fig. 1). Below LSW, Northeast Atlantic Deep water (NEADW), ISOW and DSOW circulate 
cyclonically in the LS basin (Azetsu-Scott et al., 2003; Yashayaev, 2007). NEADW is a cluster of higher salinity and colder waters than LSW; ISOW and DSOW protrude from the NEADW, with DSOW being fresher and more oxygenated than ISOW (Talley and Pickard., 2011), while ISOW evolves "en route" to become NEADW (Yashayaev and Dickson, 2008). These intermediate and deep waters supply the lower limb of the Atlantic Meridional Overturning Circulation, which redistributes heat and substances between polar and equatorial regions in the North Atlantic (e.g., Talley and McCartney, 1982; Lherminier et al., 2010). During the formation of LSW, gases and atmospheric deposition are sequestered and incorporated into the deepening water. From chlorofluorocarbons concentrations, Azetsu-Scott et al. (2005) described the structure and ventilation age (time since a water mass last had contact with the atmosphere) of the LS water column. Deep convection in the LS varies from 200 to $2000 \mathrm{~m}$ from one year to the next, depending on atmospheric conditions and stratification of the water column (Azetsu-Scott et al., 2003; Yashayaev et al., 2007). In the upper part, the newly ventilated LSW overlays LSW produced in the previous winters. Below, NEADW and DSOW have ventilation ages estimated to be 11-13, and 5-8 years (Azetsu-Scott et al., 2005). More generally, according to Yashayaev et al. (2015a), DSOW and NEADW show quasi-pentadal and multi-decadal oscillations, respectively, while LSW changes at higher frequencies. Therefore, the LS is the best location where full water column observations allow the discrimination and identification of LSW "vintages" ( $\left.\mathrm{LSW}_{\text {Year }} v s \mathrm{LSW}_{\text {Deep }}\right)$, which overlay the older NEADW/ISOW and DSOW. Year after year, every winter convection results in a variable renewal of LSW entraining substances, such as mercury ( $\mathrm{Hg}$ ), from the atmosphere into the deep layers, and the transfer of the atmospheric signal to the intermediate depths of the North Atlantic Ocean. In addition, since it is now well established that the oceanic $\mathrm{Hg}$ cycle is heavily impacted by human atmospheric 
emissions (e.g., Sunderland and Mason, 2007; Lamborg et al., 2014), it is important to appraise the anthropogenic $\mathrm{Hg}$ impregnation of the water column of the North Atlantic Ocean. Here, we report the first high-resolution $\mathrm{Hg}$ distribution pattern along a transect, which closes off the Labrador Sea from Greenland to Labrador coasts held in June 2014 during the GEOTRACESGEOVIDE cruise, i.e., after the 2014-winter convection (Fig. 1).

\section{Material and methods}

\subsection{Sampling}

Water samples were collected in the Labrador Sea between 19 and 27 June 2014, during the GeOtraces-GeOVIDE cruise onboard the R/V "Pourquoi Pas?". Seven stations (6-21 depths each) were occupied for collecting water samples for $\mathrm{Hg}$ determination (Fig. 1). Sampling and water treatment were performed using ultra-trace techniques following GEOTRACES recommendations (www.geotraces.org). During the GEOVIDE cruise, an epoxy-coated aluminium rosette, held by a Kevlar hydrowire, was deployed with acid-cleaned Teflon coated 12 L GO-FLO (General Oceanics ${ }^{\circledR}$ ) bottles initially cleaned following the GEOTRACES procedures (Cutter and Bruland, 2012). No samples were collected in the first $10 \mathrm{~m}$ below the surface in order to avoid contamination from the ship. The rosette was also equipped with probes for pressure, conductivity, temperature, dissolved oxygen, fluorescence and transmission measurements (titanium SBE model 911-plus, Sea-Bird Electronics®), in order to examine $\mathrm{Hg}$ data in relation to hydrographical profiles. Specifically, for $\mathrm{Hg}$ determination, the material in contact with the seawater samples was Teflon made or Teflon coated and acid-cleaned and rinsed with ultrapure water (Milli-Q, Millipore®) prior to utilization. Original vent fixture and sampling valves of the GO-FLO bottles were replaced with Teflon (PTFE) ones. GO-FLO bottles were sub-sampled under a laminar flow bench inside a clean container specially designed for trace metal analyses. The 
efficiency of the High-Efficiency Particulate Air filter (HEPA, $0.3 \mu \mathrm{m}$ ) in the container was checked with a Coulter Counter during the cruise. All subsequent sample treatment (including filtration through acid washed $0.45 \mu \mathrm{m}$ Nuclepore membranes) and $\mathrm{Hg}$ analyses were performed in container labs equipped with class 100 clean air supplies. Sub-samples were stored in Teflon bottles (FEP or PFA) until the on board HgT analyses, which occurred within 6 hours after sampling.

\subsection{Analyses}

In order to access to all the chemical species of $\mathrm{Hg}$ present in the sample, the release of $\mathrm{Hg}$ from its ligands was achieved by $\mathrm{BrCl}(50 \mu \mathrm{L}$ of a $0.2 \mathrm{~N}$ solution is added to a $40-\mathrm{mL}$ sample) and then the $\mathrm{Hg}^{\mathrm{II}}$ was reduced to $\mathrm{Hg}^{0}$ with $\mathrm{SnCl}_{2}(100 \mu \mathrm{L}$ of a $1 \mathrm{M}$ solution is added to a $40-\mathrm{mL}$ sample). The $\mathrm{Hg}^{0}$ vapor generated by the reduction and extracted in an argon gas flow is amalgamated on a gold trap and then released by heating into an atomic fluorescence spectrometer (AFS, Model 2500 from $\operatorname{Tekran}^{\circledR}$ ). This technique, initially described by Bloom and Crecelius (1983) and subsequently improved by Gill and Fitzgerald (1985), is now listed as US-EPA Standard Method $\mathrm{N}^{\circ} 1631$. Use of a mirrored quartz cuvette (Hellma®) allowed for an "absolute DL", defined as two times the electronic noise magnitude, as low as 1.7 femtomol. However, in practice for trace measurements, the DL is governed by the reproducibility of the blank values, and calculated as 3.3 times the standard deviation of blank values. The blank was determined on a purged $\mathrm{Hg}$-free seawater sample spiked with reagents (i.e., $\mathrm{BrCl}$ and $\mathrm{SnCl}_{2}$ ). The mean ( \pm standard deviation) of blanks measured during the present cruise was $3.2 \pm 1.0$ femtomoles. Thus, for a 40-mL seawater aliquot, the DL expressed in $\mathrm{HgT}$ concentration was $0.07 \mathrm{pmol} \mathrm{L}^{-1}$. The reproducibility (coefficient of variation of six replicate measures) varied according to the concentration level between 5 and $15 \%$. The accuracy of $\mathrm{HgT}$ measurements 
was tested using ORMS-5 certified reference material (CRM) from the National Research Council of Canada (http://www.nrc-cnrc.gc.ca/), as spike addition to a purged $\mathrm{Hg}$-free seawater sample. Measurements were always within the given confidence interval.

\section{Results and discussion}

\subsection{Water masses identification}

A full description of the oceanographic context of the GEOVIDE cruise is given by García-Ibáñez et al. (2017). The distributions of salinity and potential density $\left(\sigma_{\theta}\right)$ along the section (Fig. 2a, b) allows the identification of water masses expected in the area, consistent with previous oceanographic investigations (e.g., Stramma et al., 2004; Yashayaev et al., 2015a, Yashayaev and Loder, 2016). From surface waters downward we observed: (i) a well stratified surface layer of $150 \mathrm{~m}$ depth in the central Labrador Sea, extending down to $350 \mathrm{~m}$ on both sides of the transect, (ii) a homogenous layer, which extends down to $1400 \mathrm{~m}$ in the central Labrador Sea and corresponds to the strong 2014 winter convection (named LSW $2014-15$ according Yashayaev and Loder, 2016), (iii) a deeper LSW layer, which ranges from 1400 to $2400 \mathrm{~m}$ (named here $\mathrm{LSW}_{\text {Deep }}$, (iv) NEADW (2400-3500 m), with ISOW ( 3000 m), and (v) DSOW (>3500 m). The well-ventilated $\mathrm{LSW}_{2014-15}$, which is noticeable by high dissolved oxygen (> $280 \mu \mathrm{mol} \mathrm{L} \mathrm{L}^{-1}$, Fig. 2c), low salinity (34.8 to $34.9 \mathrm{Sp}$, Fig. $2 \mathrm{a}$ ), and by a $\sigma_{\theta}$ ranging between 27.60 and $27.75 \mathrm{~kg} \mathrm{~m}^{-3}$ (Fig. 2b), characterizes the 2014 winter convection layer. $\mathrm{LSW}_{2014-15}$ has already been described in details by Kieke and Yashayaev (2015) and Yashayaev and Loder (2016). The LSW Deep includes LSW $1987-94$ (Yashayaev and Loder, 2016), and also recent winter convections exceeding 1000 m, i.e., 2008, 2011 and 2012 winters (Yashayaev et al., 2015b); potential density of $\mathrm{LSW}_{\text {Deep }}$ ranged from 27.75 to $27.85 \mathrm{~kg} \mathrm{~m}^{-3}$. NEADW and DSOW occupy $\sigma_{\theta}$ ranges $27.85-27.9$ and $>27.9 \mathrm{~kg} \mathrm{~m}^{-3}$, respectively (Fig. 2b). 


\subsection{Mercury distribution and partitioning}

The summary statistics of the $\mathrm{HgT}_{\mathrm{UNF}}$ concentrations encountered in the various water masses are given in Table 1. Concentrations ranged from $0.25 \mathrm{pmol} \mathrm{L}^{-1}$ for sub-surface samples (St. 64, $50 \mathrm{~m}$ ) to $0.67 \mathrm{pmol} \mathrm{\textrm {L } ^ { - 1 }}$ for the deepest sample (St. 71, $3694 \mathrm{~m}$ ), averaging $0.44 \pm 0.10 \mathrm{pmol} \mathrm{L}^{-1}$ $(\mathrm{n}=113,1 \sigma)$. Generally, $\mathrm{HgT}_{\mathrm{UNF}}$ increased downward, and southward from Greenland to Labrador (Fig. 2d). High $\mathrm{HgT}_{\mathrm{UNF}}$ concentrations $\left(>0.55 \mathrm{pmol} \mathrm{L}^{-1}\right.$ ) were found all along the water column of the Labrador coast, whereas lowest $\mathrm{HgT}_{\mathrm{UNF}}$ concentrations $\left(<0.30 \mathrm{pmol} \mathrm{L}^{-1}\right)$ were found in upper waters along the Greenland coast (Fig. 2d). Concentrations of dissolved $\mathrm{Hg}$ in filtered samples $\left(\mathrm{HgT}_{\mathrm{F}}\right)$, measured in $64 \%$ of the collected samples, represented from 62 to 92 $\%$ of the unfiltered fraction depending on the station and the depth, for an overall average $\mathrm{HgT}_{\mathrm{F}} / \mathrm{HgT}_{\mathrm{UNF}}$ of $76 \pm 7 \%(\mathrm{n}=68)$. The $\mathrm{HgT}_{\mathrm{F}}$ distribution pattern is similar to $\mathrm{HgT}_{\mathrm{UNF}}$ (Fig. 2e). The highest particulate $\mathrm{Hg}$ fraction (> $30 \%$ of the $\mathrm{HgT}_{\mathrm{UNF}}$ ) was found in the top $50 \mathrm{~m}$ of the central Labrador Sea (Sts. 68 and 69), where plankton was abundant at the end of May 2014, a few weeks before our cruise (Yashayaev et al., 2015b).

Within the surface layers $(10-350 \mathrm{~m})$, Labrador Current waters exhibited statistically higher mean $\mathrm{HgT}_{\mathrm{UNF}}$ concentrations than the Greenland Current: $0.56 \pm 0.05 \mathrm{pmol} \mathrm{L}^{-1}$ vs $0.31 \pm$ 0.03 pmol L$^{-1}(t$-test, $p<0.01$, Table 1). This Hg-enrichment in the Labrador Current waters, which is also noticeable in the filtered fraction and extended to the shelf edge (Fig. 2e), is consistent with the measurements performed by Kirk et al. (2008), according to which $\mathrm{HgT}_{\mathrm{UNF}}$ concentrations ranged from 0.8 to $1.1 \mathrm{pmol} \mathrm{L}^{-1}$ in surface waters of the Hudson Strait and from 0.7 to 1.0 pmol L ${ }^{-1}$ in surface waters of the Northern Baffin Bay reaching the Labrador Sea through Davis Strait. Indeed, it has been suggested that freshwater in the Labrador inshore current originates from Hudson Bay, Baffin Bay and the Canadian Arctic (Straneo and Saucier, 
2008). Furthermore, based on a mass balance approach, using salinity, temperature, nutrients and $\delta^{18} \mathrm{O}$ data (available from the present GEOVIDE cruise, and HUD2014007 and JR302 cruises also held in May-June 2014), freshwater sources in the southern Labrador shelf and slope have been sorted out into sea ice melt $(\mathrm{sim})$, meteoric water $(m w)$ and Pacific water $(p w)$ (Benetti et al, 2016). Main observations were: (i) the surface freshening was maximum in the top $25 \mathrm{~m}$ waters, (ii) the $p w$ fraction decreased from the coast to the outer part of the shelf, (iii) highest $m w$ fractions were observed in the freshest surface water of the inner shelf, and (iv) brine rejection (negative sim) were found in the subsurface layer of the inner shelf. Thus, the negative sim and the high $p w$ values suggest that the coast current carries waters originating to a large extent from the Canadian Arctic through Davis Strait (Benetti et al., 2016). In that context, the Hgenrichment could be due to a high $\mathrm{Hg}$ content of $m w$, associated with the fluvial runoff producing the low salinity cold waters outflowing from the Canadian Arctic Archipelago, Baffin and Hudson Bays (Fig. 2a). This hypothesis is strongly supported by the modelling by Fisher et al. (2012), who suggested that rivers are the dominant source of $\mathrm{Hg}$ to the Arctic Ocean, and recent finding by Obrist et al. (2017) on the high tundra soil Hg concentrations, which might explain the large amounts of $\mathrm{Hg}$ transported by the Arctic rivers (Coquery et al., 1995; Schuster et al., 2011). Alternatively, but not exclusively, (i) $p w$ may content relatively $\mathrm{Hg}$-rich waters, since $\mathrm{HgT}$ concentrations above the thermocline in the North Pacific (which enter the Arctic Ocean through the Bering Strait) range from 0.5-1.9 pmol L $\mathrm{p}^{-1}$ according to Sunderland et al. (2009) and Munson et al. (2015), and (ii) brine in the Labrador Current may also be Hg-enriched, as already observed at the time of the ice-pack formation in the Southern Ocean (Cossa et al., 2011). Anyhow, more results are needed to solve the issue of the precise origin(s) of the Hg-enrichment in the Labrador Current. 
Mercury enrichment in both dissolved and particulate phases is also noticeable in the deep waters along the southward Labrador slope current (Fig. $2 \mathrm{~d}$ and e). Two sources can be proposed to explain this deep-water HgT_enrichment in both filtered and unfiltered samples. Labrador Current borne organic rich particles can accumulate along the Labrador shelf and rise, a part of them releasing their associated $\mathrm{Hg}$ to the $<0.45 \mu \mathrm{m}$ dissolved fraction during organic matter remineralisation. Labrador Current waters in the LS waters have high particulate organic carbon to particulate organic nitrogen ratios suggesting the influence of detritus from freshwater inputs (Fragoso et al., 2017). In addition, in Davis Strait deep waters, i.e., at the entrance of LS, the presence of organic matter linked to microbial biomass, bacterial respiration, and degradation of the organic matter has been observed (Gonçalves-Araujo et al., 2016). Alternatively, the enriched $\operatorname{HgT}_{\mathrm{UNF}}$ may originate from the NEADW/ISOW, which circulate cyclonically at depth in the Labrador Sea; however, the lateral asymmetry of the $\mathrm{HgT}_{\mathrm{UNF}}$-enrichment in the deep LS does not support the latter hypothesis (Fig. 2d and e).

In the convection zone (Sts, 68, 69,71 and 77), the average $\mathrm{HgT}_{\mathrm{UNF}}$ concentration in the $\mathrm{LSW}_{2014-15}$ is low $\left(0.38 \pm 0.05 \mathrm{pmol} \mathrm{L}^{-1}, \mathrm{n}=23\right)$, and among the lowest ever measured in oceanic waters for such intermediate depths. Below the $\mathrm{LSW}_{2014-15}$ layer, $\mathrm{HgT}_{\mathrm{UNF}}$ concentrations increase gradually in the $\mathrm{LSW}_{\text {Deep }}(0.40 \pm 0.07 \mathrm{pmol} \mathrm{L}, \mathrm{n}=26)$ up to mean concentrations of $0.52 \pm 0.06$ $(\mathrm{n}=21)$ and $0.55 \pm 0.07 \mathrm{pmol} \mathrm{L}^{-1}(\mathrm{n}=6)$ in the NEADW and DSOW, respectively (Table 1). It is worthwhile to note that $\mathrm{HgT}_{\mathrm{UNF}}$ concentrations reported here for the LSWs, contrast with the higher concentration range observed during the International Oceanographic Commission (IOC) Baseline Trace Metal cruise in August 1993 in the North Atlantic. At that time, the Hg concentrations in the LSWs layers (300-2000 m) ranged from 0.55 to $1.64 \mathrm{pmol} \mathrm{L}^{-1}$, averaging $1.14 \pm 0.36 \mathrm{pmol} \mathrm{L}^{-1}(\mathrm{n}=7)$ (recalculated from Sts. 2 and 3 in figure 3, Mason et al., 1998). A 
decrease in HgT concentration over the last three decades supports the estimated decline in $\mathrm{Hg}$ concentrations of subsurface waters of the North Atlantic by models (e.g., Soerensen et al., 2012). Thus, the $\mathrm{HgT}_{\mathrm{UNF}}$ or $\mathrm{HgT}_{\mathrm{F}}$ concentrations increase with depth (and water age) may indicate a decrease in $\mathrm{Hg}$ incorporation rate in the LSW with time, but it may also be the result of changes in the intensity of $\mathrm{Hg}$ regeneration in the water column. Indeed, the dissolved oxygen distribution, which shows a minimum at depth, is typical of the occurrence of an active degradation of organic matter in the LS (Fig. 2c), which may promote the release/mobilization of Hg from the particles at depth.

\subsection{Mercury biogeochemical behavior}

As already described, the $\mathrm{Hg}$ deposited to oceanic surface water may be re-emitted to the atmosphere or incorporated with primary production and transferred downward with settling organic particles. During the organic matter regeneration at depth, particles release a part of their associated $\mathrm{Hg}$ (e.g., Mason et al., 2012). The LS is not an exception, and atmospheric deposition, biological uptake, and regenerative processes control the $\mathrm{Hg}$ distribution. Indeed, the U-shape of the $\operatorname{HgT}_{\mathrm{F}}$ vs apparent oxygen utilization (AOU) illustrates this behavior (Fig. 3). Note that AOU presents negative values when waters are saturated with oxygen, whereas positive values indicate the intensity of oxygen consumption during the organic matter mineralization by microbial respiration. In the oxygen saturated zone, $\operatorname{HgT}_{\mathrm{F}}$ concentrations are stable when $\mathrm{AOU}$ increases, indicating the common atmospheric source of both oxygen and $\mathrm{Hg}$; inversely, with positive AOU values, i.e. in the regeneration zones, $\mathrm{HgT}_{\mathrm{F}}$ concentrations increase when $\mathrm{AOU}$ increases from 0 to $60 \mu \mathrm{mol} \mathrm{L} \mathrm{L}^{-1}$ (Fig. 3). This latter relationship illustrates a nutrient-like behavior of $\mathrm{Hg}$ in the LS, as already noticed in the eastern part of the North Atlantic Ocean (Cossa et al., 2004). The same type of relationship with $\mathrm{AOU}$ is also significant with $\mathrm{HgT}_{\mathrm{UNF}}$, meaning that $\mathrm{HgT}_{\mathrm{F}}$ 
dominates $\mathrm{HgT}_{\mathrm{UNF}}$ except in surface waters where particles may be abundant (Fig. SI-1), and also that $\operatorname{HgT}_{\mathrm{UNF}}$ is a good proxy for $\mathrm{HgT}_{\mathrm{F}}$ below $100 \mathrm{~m}$.

As proposed by Lamborg et al. (2014) oceanic Hg distributions are a combination of preanthropogenic, nutrient-like and transient signals resulting from human activities over the past several centuries. An estimate of the anthropogenic $\mathrm{Hg}$ concentrations $\left(\mathrm{Hg}_{\mathrm{anth}}\right)$ can be inferred from the difference between measured $\mathrm{HgT}_{\mathrm{UNF}}$ concentrations (assuming $\operatorname{HgT}_{\mathrm{UNF}}$ as a proxy of $\left.\mathrm{HgT}_{\mathrm{F}}\right)$ and the concentrations predicted based on a worldwide relationship between deep ocean HgT concentrations and remineralized phosphate (Lamborg et al., 2014). According to the same authors, the HgT-to-remineralized phosphate ratios are significantly increased in North Atlantic intermediate and deep waters. The $\mathrm{Hg}_{\text {anth }}$, calculated here (Fig. SI-2), represents a mean of $36 \%$ of the $\mathrm{HgT}_{\mathrm{UNF}}$ in the LS, with the highest fraction $(>80 \%)$ in sub-surface and lowest fraction $(<$ $15 \%$ ) near the bottom in the central LS (Fig. 2f). These results are consistent with modeling results by Sunderland and Mason (2007), which indicated that surface waters of much of the Atlantic Ocean and deep water in North Atlantic contain a large inventory of historically deposited $\mathrm{Hg}_{\mathrm{anth}}$, with an enhancement factor in seawater that varies around $30-60 \%$. The distribution pattern of $\mathrm{Hg}_{\text {anth }}$ shows that the highest $\mathrm{Hg}_{\text {anth }}$ is associated with upper waters, especially in the Labrador Current (Fig. 2f), which carries organic/Hg-rich freshwaters from the Canadian Arctic Archipelago waters (see discussion above, section 3.2). In addition, slightly higher $\mathrm{Hg}_{\text {anth }}$ concentrations can be identified in bottom waters along the rise of the Labrador shelf (Fig. SI-2, Fig. 2f)). This small Hg-enrichment should result from $\mathrm{Hg}$ mobilized during the remineralization of the organic matter originating from the Canadian Arctic Archipelago (see above). 


\section{Summary and Conclusions}

In summary, the HgT distribution in the LS water column is characterized by a nutrient-like behavior superimposed by Hg-enrichment originating from the Canadian Arctic Archipelago waters carried by the Labrador Current. This excess $\mathrm{Hg}$ is transferred southward, in surface waters with the Labrador Current, and at depth with the lower limb of the Atlantic Meridional Overturning Circulation via the Deep Western Boundary Current. This process should increase with the expected permafrost thawing over the next decades, which generates organic/ $\mathrm{Hg}$-rich freshwaters to the Canadian Arctic Archipelago waters. On the other hand, the $\mathrm{Hg}$ increase between the shallow LSW layer (LSW 2014-15) and the deep LSW layer (LSW 1987-94) are well explained by $\mathrm{Hg}$ regeneration in the water column. The magnitude of the $\mathrm{Hg}$ regeneration probably outweighs the expected decrease in $\mathrm{Hg}$ incorporation into the LSWs at the time scale of the age of the waters present in the LS (i.e., $\sim 20$ years).

\section{Author information}

Corresponding Authors E-mail: dcossa@ifremer.fr. Phone: +1-514-439-8254.

Daniel Cossa: https://www.researchgate.net/profile/Daniel_Cossa

\section{Acknowledgments.}

The first thanks are for J. Boutorh, M. Cheize, J.-L. Menzel and R. Shelley who were in charge of the ultra-trace sampling organization; they are commended for its successful achievement. Thanks are also due to other members of the GEOVIDE team for participating to data acquisition: F. Alonso Pérez, R. Barkhouse, V. Bouvier, P. Branellec, L. Carracedo Segade, M. Castrillejo, L. Contreira, E. de Saint Léger, N. Deniault, F. Desprez de Gesincourt, L. Foliot, D. Fonseca Pereira, E. Grossteffan, P. Hamon, C. Jeandel, C. Kermabon, F. Lacan, P. Le Bot, M. Le Goff, A. Lefebvre, S. Leizour, N. Lemaitre, O. Menage, F. Pérault, F. Planchon, A. Roukaerts, V. Sanial, R. Sauzède, and Y. Tang. A special thank is also due to the R/V "Pourquoi Pas?" crew 
and Captain G. Ferrand. This research was funded by the French National Research Agency (ANR-13-BS06-0014), the French National Center for Scientific Research (CNRS-LEFE-CYBER), the Global Mercury Observation System (GMOS, N'265113 European Union project), and the European Research Council (ERC-2010-StG-20091028). For this work M.I. García-Ibáñez and F.F. Pérez were supported by the Spanish Ministry of Economy and Competitiveness through the BOCATS (CTM2013-41048-P) project co-funded by the Fondo Europeo de Desarrollo Regional 2014-2020 (FEDER) 


\section{References}

Azetsu-Scott, K., Jones, E.P., Yashayaev, I., Gershey, R.M. 2003. Time series study of CFC concentrations in the Labrador Sea during deep and shallow convection regimes (1991-2000). J. Geophys. Res., 108 (C11), 3354.

Azetsu-Scott, K., Jones, E.P., Gershey, R.M. 2005. Distribution and ventilation of water masses in the Labrador Sea inferred from CFCs and carbon tetrachloride. Mar. Chem., 94, 55-66.

Benetti, M., Reverdin, G., Lique, C., Yashayaev, I., Holliday, N.P., Tynan, E., Torres-Valdes, S., Lherminier, P., Tréguer, P., Sarthou, G. 2016. Composition of freshwater in the spring of 2014 on the southern Labrador shelf and slope, J. Geophys. Res. Oceans, 122, 1102-1121, doi:10.1002/2016JC012244.

Bloom, N.S., Crecelius, E.A. 1983. Determination of mercury in seawater at sub-nanogram per liter levels. Mar. Chem., 14, 49-59.

Coquery, M., Cossa, D, Martin, J.-M. 1995. The Distribution of Dissolved and Particulate Mercury in Three Siberian Estuaries and Adjacent Arctic Coastal Waters. Water, Air, Soil Pollut., 므, 653-664.

Cossa, D., Cotté-Krief, M.-H., Mason R. P., Bretaudeau-Sanjuan, J. 2004. Total mercury in the water column near the shelf edge of the European continental margin, Mar. Chem., 90, 21-29, doi:10.1016/j.marchem.2004.02.019.

Cossa, D., Heimbürger L.-E., Lannuzel D., Rintoul S.R., Butler E.C.V., Bowie A.R., Averty B., Watson R.J., Remenyi T. 2011. Mercury in the Southern Ocean. Geochim. Cosmochim. Acta, 75, 4037-4052.

Cutter, G.A., Bruland, K.W. 2012. Rapid and noncontaminating sampling system for trace elements in global ocean surveys. Limnol. Oceanogr. - Methods, 10, 425-436, doi:10.4319/lom.2012.10.425, 2012.

Dickson, R.R., Meincke, J., Rhines, P., 2008. Arctic-subarctic ocean fluxes: Defining the role of the northern seas in climate. Arctic-Subarctic Ocean Fluxes. Dickson, R.R., Meincke, J., Rhines, P. Eds., Springer, 1-13. 
Fisher, J.A., Jacob, D.J., Soerensen, A.L., Amos, H.M., Steffen, A., Sunderland, E.M. 2012. Riverine source of Arctic Ocean mercury inferred from atmospheric observations. Nat. Geosci., 5, 499504, doi:10.1038/ngeo147.

Fitzgerald, W.F., Lamborg, C.H., Hammerschmidt, C.R. 2007. Marine biogeochemical cycling of mercury. Chem. Rev. 107, 641-662.

Fragoso, G.M., Poultron, A.J., Yashayaev, I.M., Head, E.J.H., Stinchcombe, M.C., Purdie, D.A. 2017. Biogeographical patterns and environmental controls of phytoplankton communities from contrasting hydrographical zones of the Labrador Sea. Prog. Oceanogr., 141 (2016) 212-226.

García-Ibáñez, M. I., Pérez, F. F., Lherminier, P., Zunino, P., Treguer, P. 2017. Water mass distributions and transports for the 2014 GEOVIDE cruise in the North Atlantic. Biogeosciences (in press).

Gill, G.A., Fitzgerald, W.F. 1985. Mercury Sampling of Open Ocean Waters at the Picogram Level. Deep Sea Res. 32A, 287-297.

Gonçalves-Araujo, R., Granskog, M.A., Bracher, A., Azetsu-Scott, K., Dodd, P.A., Stedmon, C.A. 2016. Using fluorescent dissolved organic matter to trace and distinguish the origin of Arctic surface waters. Sci. Rep., 6:33978, DOI: 10.1038/srep33978.

Kieke, D., Yashayaev, I. 2015. Studies of Labrador Sea Water formation and variability in the subpolar North Atlantic in the light of international partnership and collaboration. Prog. Oceanogr., 132, 220-232.

Kirk, J.L., St. Louis, V.L., Hintelmann, H., Lehnherr, I., Else, B., Poissant, L. 2008. Methylated mercury species in marine waters of the Canadian High and Sub Arctic. Environ. Sci. Technol., 42, 8267-8373. DOI: 10.1021/es801635m.

Lamborg, C.H., Hammerschmidt, C.R., Bowman, K.L., Swarr, G.J., Munson, K.M., Ohnemus, D.C., Lam, P.J. Heimbürger, L.-E., Rijkenberg, M.J.A., Saito, M.A. 2014. A global ocean inventory of anthropogenic mercury based on water column measurements. Nature, 512, 65-68.

Lamborg, C.H., Hammerschmidt, C.R., Bowman, K.L. 2016. An examination of the role of particles in oceanic mercury cycling. Phil. Trans. R. Soc., A 374, 20150297. doi.org/10.1098/rsta.2015.0297. 
Lherminier, P., Mercier, H., Huck, T., Gourcuff, C., Perez, F. F., Morin, P., Sarafanov, A., Falina, A. 2010. The Atlantic Meridional Overturning Circulation and the Subpolar Gyre observed at the A25-OVIDE Section in June 2002 and 2004. Deep-Sea Res. I, 57, 1374-1391. Mason, R.P., Choi, A.L., Fitzgerald, W.F., Hammerschmidt, C.R., Lamborg, C.H., Soerensen, A.L., Sunderland, E.M. 2012. Mercury biogeochemical cycling in the ocean and policy implications. Environ. Res. 119, 101-117.

Mason, R.P., Rolfus, K.R., Fitzgerald, W.F. 1998. Mercury in the North Atlantic. Mar. Chem., 61, 37-53.

Munson, K.M., Lamborg, C.H., Swarr, G.J., Saito, M.A. 2015. Mercury species concentrations and fluxes in the Central Tropical Pacific Ocean, Global Biogeochem. Cycles, 29, doi:10.1002/2015GB005120.

Obrist, D., Agnan, Y., Jiskra, M., Olson, C.L. Colegrove, D.P., Hueber, J., Christopher W. Moore, C.W., Sonke, J.E., Helmig, D. 2017. Tundra uptake of atmospheric elemental mercury drives Arctic mercury pollution. Nature, 547, 201-204, doi:10.1038/nature22997.

Pirrone, N., Mason, R.P., 2009. Mercury Fate and Transport in the Global Atmosphere Emissions, Measurements, and Models. 602 pp. Springer Science, DOI: 10.1007/978-0-38793958-2-1.

Schuster, P.F., Striegl, R.G., Aiken, G.R., Krabbenhoft, D.P., Dewild, J.F., Butler, K., Kamark, B., Dornblaser, M. 2011. Mercury export from the Yukon river basin and potential response to a changing climate. Environ. Sci. Technol. 45, 9262-9267.

Soerensen, A.L., Jacob, D.J., Streets, D.G., Witt, M.L.I., Ebinghaus, R., Mason, R.P., Andersson, M., Sunderland, E.M. 2012. Multi-decadal decline of mercury in the North Atlantic atmosphere explained by changing subsurface seawater concentrations. Global Biogeochem. Cycles, 39, L21810, doi:10.1029/2012GL05736.

Sunderland, E.M., Mason, R.P. 2007. Human impacts on open ocean mercury concentrations, Global Biogeochem. Cycles, 21, GB4022, doi:10.1029/2006GB002876.

Sunderland, E.M., Krabbenhoft, D.P., Moreau, J.W., Strode S.A., Landing, W.M. 2009. Mercury sources, distribution, and bioavailability in the North Pacific Ocean: Insights from data and models. Global Biogeochem. Cycle, 23, GB2010, doi:10.1029/2008GB003425. 
Straneo, F., Saucier, F. 2008. The outflow from Hudson Strait and its contribution to Labrador Current. Deep Sea Res., Part I, 55, 926-946.

Stramma, L., Kieke, D., Rhein, M., Schott, F., Yashayaev, I., Koltermann, K.P. 2004. Deep water changes at the western boundary of the subpolar North Atlantic during 1996 to 2001. Deep-Sea Res., Part I, 51(8), 1033-1056.

Talley, L.D., Pickard, G.L. 2011. Atlantic Ocean. Chap 9. In: Descriptive Physical

Oceanography: An Introduction. Talley, L.D., Pickard, G.L., Emery, W.J. eds., pp 245-301.

Sixth ed. Academic Press, Amsterdam, Boston, ISBN: 978-0-7506-4552-2.

Talley, L.D., McCartney, M.S. 1982. Distribution and circulation of Labrador Sea Water. J. Phys. Oceanogr.,12, 1189-1205.

Yashayaev, I. 2007. Hydrographic changes in the Labrador Sea, 1960-2005. Prog. Oceanogr., 73, 242-276.

Yashayaev, I., Seidov, D., Demirov, E. 2015a. A new collective view of oceanography of the Arctic and North Atlantic basins. Prog. Oceanogr. 132, 1-21.

Yashayaev, I., Head, E.J.H., Azetsu-Smith, K. Ringuette, M., Wang, Z., Anning, J., Punshon, S. 2015b. Environmental Conditions in the Labrador Sea during 2014. Northwest Atlantic Fisheries Organization, Scientific Council Meeting (June 2015), Serial N N6436, NAFO SCR Doc. 15/015. 33 pages.

Yashayaev, I., Dickson, R.R. 2008. Transformation and fate of over-flows in the northern North Atlantic. Chap. 21. In: Arctic-Subarctic Ocean Fluxes: Defining the Role of the Northern Seas in Climate. R.R. Dickson, J. Meincke, P. Rhines eds., pp. 505 - 526, Springer, New York.

Yashayaev, I., Loder, J.W. 2016. Recurrent replenishment of Labrador Sea Water and associated decadal scale variability. J. Geophys. Res. Oceans, 121, 8095-8114, doi:10.1002/2016JC012046. 
Figures
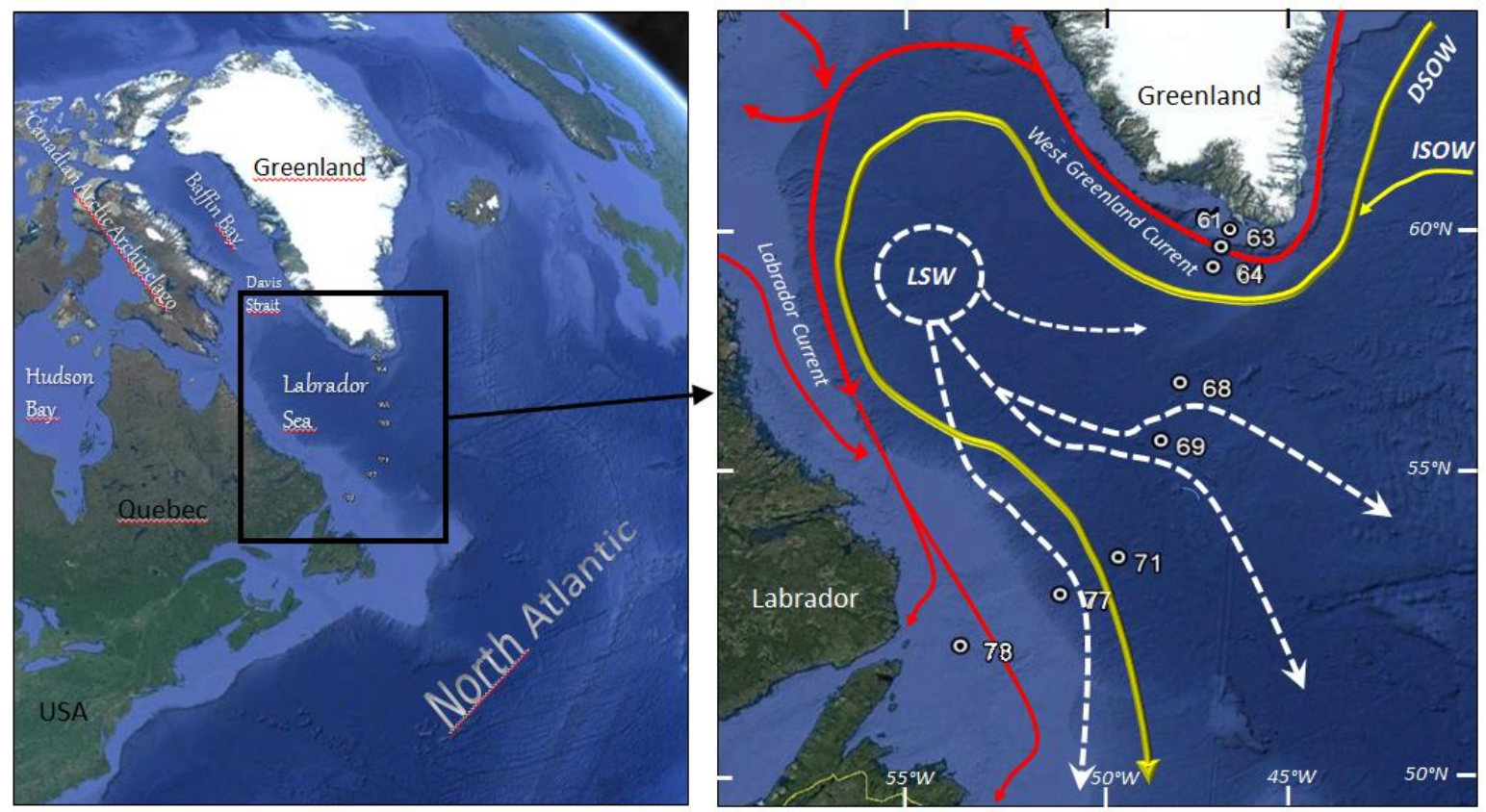

Figure 1. Stations location along the transect from Greenland to Labrador in the Labrador Sea. 

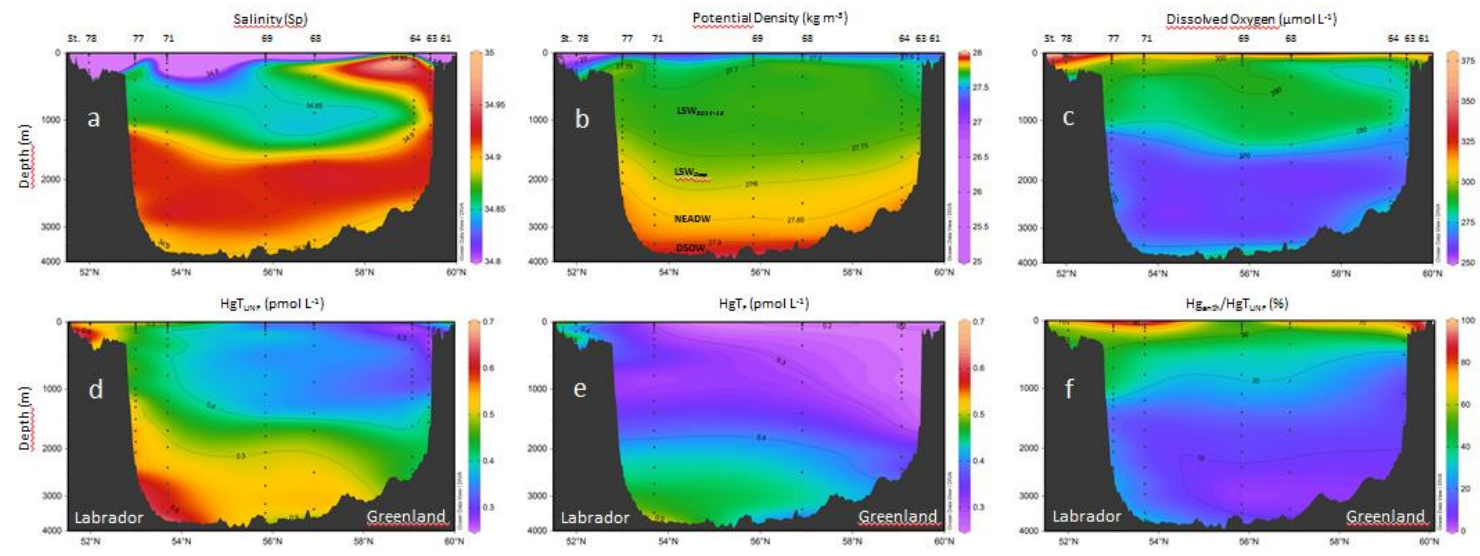

Figure 2. Distributions of salinity, potential density, dissolved oxygen, total mercury in unfiltered samples $\left(\mathrm{HgT}_{\mathrm{UNF}}\right)$, total mercury in filtered samples $\left(\mathrm{HgT}_{\mathrm{F}}\right)$ and anthropogenic mercury fraction $\left(\mathrm{Hg}_{\mathrm{anth}} / \mathrm{HgT}_{\mathrm{UNF}}\right)$ along the transect in the Labrador Sea. 


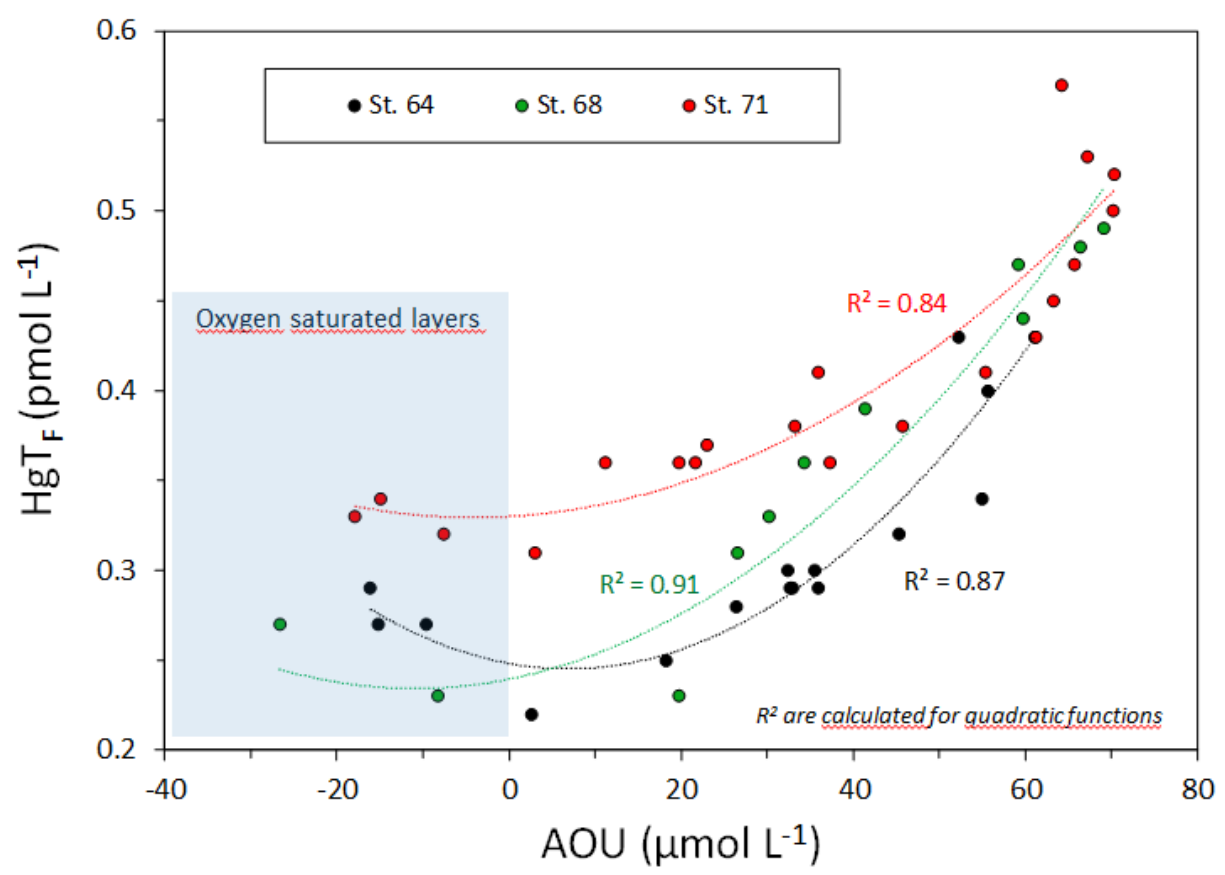

Figure 3. Relationship between total mercury in filtered samples $\left(\operatorname{HgT}_{\mathrm{F}}\right)$ and apparent oxygen utilization (AOU) in the Labrador Sea. 


\section{Table}

Table 1. Summary statistics of the $\mathrm{HgT}_{\mathrm{UNF}}$ concentrations $\left(\mathrm{pmol} \mathrm{L}^{-1}\right)$ in various water masses of the Labrador Sea.

\begin{tabular}{lcccc}
\hline Water mass $\left(\sigma_{\theta}, \mathrm{kg} \mathrm{m}^{-3}\right)$ & Mean & $\begin{array}{c}\text { Standard } \\
\text { deviation }\end{array}$ & $\mathrm{N}$ & Range \\
\hline $\begin{array}{l}\text { Surface Central Labrador Sea } \\
(<27.60)\end{array}$ & 0.38 & 0.060 & 21 & $0.29-0.50$ \\
Greenland Current $(<27.65)$ & 0.31 & 0.034 & 7 & $0.25-0.35$ \\
Labrador Current $(<27.68)$ & 0.56 & 0.046 & 9 & $0.49-0.61$ \\
LSW $2014-15(27.69-27.75)$ & 0.38 & 0.050 & 23 & $0.31-0.47$ \\
LSW & 0.40 & 0.069 & 26 & $0.39-0.52$ \\
NEADW $(27.75-27.80)$ & 0.52 & 0.062 & 21 & $0.39-0.62$ \\
DSOW $(>27.90)$ & 0.55 & 0.071 & 6 & $0.49-0.66$ \\
\hline
\end{tabular}

